\title{
Yöneticilerin Liderlik Özelliklerinin Çalışanların Örgütsel Vatandaşlık Davranışı Sergilemelerinin Üzerindeki Etkisi: Perakende Sektöründe Bir Araştırma (The Effect of Managers' Leadership Styles on Employees' Organizational Citizenship Behaviour: A Research in Retail Sector)
}

\section{Nilüfer RÜZGAR iDa}

a Bursa Teknik Üniversitesi, İnsan ve Toplum Bilimleri Fakültesi, İşletme Bölümü, Bursa, Türkiye. nilufer.ruzgar@btu.edu.tr

\begin{tabular}{|c|c|}
\hline MAKALE BİLGİSI & ÖZET \\
\hline Anahtar Kelimeler: & maç - Sürekli değişimin kaçınılmaz olduğu rekabetçi \\
\hline Liderli & nemli kaynak olan insan kaynağının \\
\hline Görev Yönelimli Liderlik & İnsan kaynağının elde tutulması ise, özellikle iş gücü devir oranının diğer sektörlere nazaran \\
\hline İlişki Yönelimli Liderlik & daha yüksek olduğu perakende sektöründe, daha güç olmaktadır. Bu bağlamda, uygun ve etkili \\
\hline Örgütsel Vatandaşlık Davranışı & 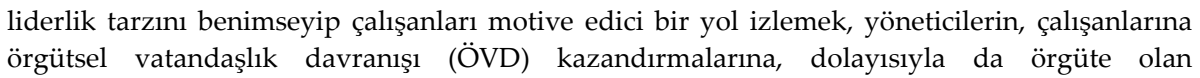 \\
\hline Gönderme Tarihi 26 Aralık 2018 & bağlılıklarının artarak elde tutulmalarına yardımcı olabilmektedir. Yöneticilerin görev yönelimli \\
\hline Revizyon Tarihi 10 Mayıs 2019 & ya da ilişki yönelimli liderlik tarzlarından hangisini benimsedikleri, çalışanların, ekstra gönüllü \\
\hline Kabul Tarihi 25 Mayıs 2019 & $\begin{array}{l}\text { davranışlar olarak da bilinen ÖVD sergilemeleri üzerinde son derece etkili olmaktadır. Buradan } \\
\text { yola çıarak bu çalışmanın amacı, perakende sektöründe faaliyet gösteren ve Türkiye'nin önde }\end{array}$ \\
\hline Makale Kategorisi: & gelen market zincirlerinden biri olan $X$ süpermarketin Bursa ili Nilüfer ilçesindeki 5 \\
\hline Araştırma Makalesi & $\begin{array}{l}\text { mağazasında çalışanların, ÖVD sergilemelerinin üzerinde yöneticilerin görev yönelimli ya da } \\
\text { ilişki yönelimli liderlik tarzlarını benimsemelerinin etkisini ölçmektir. }\end{array}$ \\
\hline
\end{tabular}

Yöntem - Araştırma yöntemi olarak anket uygulaması tercih edilmiştir. Bu kapsamda çalışanlara üç bölümden oluşan bir anket uygulanmıştır. İlk bölümde, katılımcıların demografik özelliklerini belirlemeyi amaçlayan sorulardan oluşan bir ölçek bulunmaktadır. İkinci bölümde, Northouse (2004) tarafından geliştirilen "Liderlik Tarzı Ölçeği" bulunmaktadır. Üçüncü bölümde ise, Vey ve Campbell (2004) ile Williams ve Shaw (1999)'ın çalışmalarından faydalanılarak Şeşen ve Basım (2006) tarafından geliştirilen "Örgütsel Vatandaşlık Davranışı Ölçeği" bulunmaktadır. Toplam 85 katılımcıdan elde edilen veriler, SPSS 20.0 paket programında analiz edilmiştir.

Bulgular - SPSS 20.0 paket programında yapılan analiz sonuçlarına göre, ilişki yönelimli ve görev yönelimli liderlik tarzlarının çalışanların centilmenlik, nezaket ve vicdanlılık davranışları üzerinde istatistiksel olarak anlamlı bir etkisi bulunmaktadır.

Tartışma - Araştırmanın amacı çerçevesinde elde edilen bulgulara bakıldığında, liderlerin hem ilişki hem de görev yönelimli liderlik tarzlarını benimsemelerinin hem kişilerarası ilişkileri güçlendirici etkisi olmasından hem de görevleri layıkıyla tamamlama gerekliliği sebebiyle çalışanların yaptıkları işe daha çok odaklanmalarından dolayı, örgütsel vatandaşlık davranışı geliştirilmesinde etkili olduğu düşünülmektedir. Dolayısıyla liderlik tarzları ile örgütsel vatandaşlık davranışı arasında pozitif yönde anlamlı bir ilişki bulunmaktadır denilebilmektedir. Literatürde yapılmış olan benzer çalışmalara bakıldığında ise, genel olarak liderliğin örgütsel vatandaşlık davranışları üzerinde etkisi olduğu ve kimi durumlarda güven faktörünün moderatör etkiye sahip olduğu görülmektedir. Bu kapsamda yapılan çalışmalar daha ziyade dönüşümcü (transformasyonel) ve karizmatik liderlik çerçevesinde olsa da, mevcut çalışma ile benzer olarak liderlik tarzları ile örgütsel vatandaşlık davranışı arasında pozitif yönde anlamlı bir ilişki olduğu görülmüştür.

\begin{tabular}{l}
\hline ARTICLE INFO \\
\hline Keywords: \\
Leadership Styles \\
Task Oriented Leadership \\
Relationship Oriented \\
Leadership \\
Organizational Citizenship \\
Behaviour \\
\hline
\end{tabular}

ABSTRACT

Purpose - In the competitive market environment, in which constant change is inevitable, it is very hard to keep the workforce, namely human resources, for the long term. Especially in retail sector, when compared to the other sectors, it is harder to keep the work force for the long term, because of higher turnover rates. In this sense, if the managers adopt appropriate and effective leadership styles, they would be able to motivate the employees and thus, making them adopt organizational citizenship behaviour (OCB), which will contribute to the higher commitment levels. Managers' adoption of either task oriented or relationship oriented leadership style, is

Önerilen Atıf/ Suggested Citation:

Rüzgar, N. (2019). Yöneticilerin Liderlik Özelliklerinin Çalışanların Örgütsel Vatandaşlık Davranışı Sergilemelerinin Üzerindeki Etkisi: Perakende Sektöründe Bir Araştırma, İşletme Araştırmaları Dergisi, 11 (2), 964-975. 
Received 26 December 2018 Revised 10 May 2019 Accepted 25 May 2019

Article Classification: Research Article known to have a great impact on employees' adoption of OCB. From this point of view, the aim of this research is to examine the effect of managers' adoption of leadership styles on employees adoption of OCB, in X supermarket's 5 branches in the city of Bursa, Nilüfer district.

Design/methodology/purpose - The employees are applied a survey, which consists 3 scales. The first scale is of demographical questions. The second scale is "Leadership Style Scale" that is developed by Northouse (2004). The third and the last scale is "Organizational Citizenship Behaviour Scale", that is developed by Şeşen and Basım (2006) by referring to the studies of Vey and Campbell (2004) and Williams and Shaw (1999). A total of 85 participants have responded to the surveys and the data gathered, is analysed via SPSS 20.0 package programme.

Findings - According to the findings task-oriented and relationship oriented leadership styles have statistically significant effects on employees' sportmanship, courtesy and conscientiousness behaviours.

Discussion - When the findings are evaluated in this context of the research purpose, the fact that relationship oriented style strengthens the bound among the employees and task oriented style makes the employees focus on their main duties in order to complete the task, leaders adoption of both relationship oriented and task oriented leadership styles, is thought to be effective on employees displaying organizational citizenship behaviour. Therefore, it can be suggested that there is a statistically significant relationship between leadership styles and organizational citizenship behaviour. The relevant studies in the literature prove that in general terms leadership has impact on organizational citizenship behaviour. In addition, in some cases trust factor acts as moderator. Although the studies that are done in this context focus on transformational and charismatic leadership styles, it has been proved that there is a statistically significant relationship between leadership styles and organizational citizenship behaviour, as it is proved in this current study.

\section{Giriş}

Örgütsel amaçlara ulaşılması, rekabet avantajı elde etmenin en önemli kaynağı olan insan sayesinde gerçekleşebilmektedir. Ancak günümüzde değişen iş çevresi yapısı, değişen ekonomik şartlar, değişen yasal ve politik yaptırımlar ve de en önemlisi değişen nesiller, insan kaynağının etkili ve bilinçli bir şekilde yönetilmesini zaruri kılmaktadır. Bu bağlamda da yöneticilerin liderlik tarzları, görev yönelimli ya da ilişki yönelimli olmaları kapsamında, çalışanların etkin bir biçimde yönetilerek örgütsel vatandaşlık davranışı (ÖVD) sergilemeleri üzerinde son derece etkili olmaktadır.

Görev yönelimli liderler, daha çok yapılacak işlerin gerçekleşip gerçekleşmediğine odaklanırken ilişki yönelimli liderler, çalışanlarıyla olan iletişiminin en iyi düzeyde olmasına ve onları motive etmeye odaklanarak örgütsel verimliliğe tatmin olmuş bir iş gücü vasıtasıyla ulaşmayı amaçlamaktadır (Fiedler, 1964: 152).

"Vatandaşlık" kavramı ilk ortaya çıktığı dönemlerde, mevcut yapıyı/sistemi koruyup devamlılı̆̆ını sağlamaya yönelik olan ve gönüllü olarak gerçekleştirilen yardımsever ve işbirlikçi tutumlar olarak ifade edilmiştir (Katz ve Kahn, 1966:76; Organ ve Konovsky, 1989:158). Bu davranışlar, ilerleyen dönemlerde prososyal (Brief ve Motowidlo, 1986:710), bağlamsal performans (Borman ve Motowidlo, 1993:73) ve görev ötesi davranışlar (Van Dyne, Cummings ve Parks, 1995:216) olarak sınıflandırılmışlardır. Organ (1988:4) ise bu davranışların bütününü "örgütsel vatandaşlık" olarak adlandırıp literatüre kazandırmıştır. Örgütsel vatandaşlık davranışlarına; iş arkadaşlarına yardımcı olma, gönüllü olarak fazla mesai yapma, işe yeni başlayan çalışanların sosyalleşmelerine yardımcı olma gibi eylemler örnek olarak verilebilmektedir (Bergeron, Shipp, Rosen ve Furst, 2013:4).

ÖVD, son dönemlerde akademik anlamda oldukça ilgi çekmeye başlamış bir araştırma alanıdır. ÖVD’nin elle tutulamaz, soyut olmasından dolayı, ölçülmesi ve ödüllendirilmesi çok mümkün olamamaktadır. Ancak, Podsakoff, MacKenzie, Paine ve Bachrach (2000:517), yapmış oldukları çalışmalarda uyguladıkları ölçekler vasıtasıyla ÖVD'nin örgütsel etkililiği \%18'den \%35 seviyelerine çıkardığını istatistiksel olarak ortaya koymuşlardır (Zhang, 2011:2).

$\mathrm{Bu}$ çalışmada yöneticilerin görev yönelimli ya da ilişki yönelimli liderlik tarzını benimsemelerinin, çalışanların ÖVD sergilemeleri üzerindeki etkisini ölçmek amaçlanmıştır. Türkiye'de perakende sektöründe iş gücü devir oranının diğer sektörlerle kıyaslandığında daha yüksek olmasından dolayı (Tuna, 2007: 46), market çalışanları üzerinde bir araştırma gerçekleştirilmek istenmiş ve çalışmanın örneklemi $X$ marketinin Bursa ili Nilüfer ilçesinde faaliyet gösteren 5 şubesindeki çalışanlar olarak belirlenmiştir. 


\section{Görev Yönelimli Liderlik}

Görev yönelimli liderliğin, liderin/yöneticinin örgütsel amaçlara ve istenen standartlara ulaşmak adına gerçekleştirilmesi gereken görevlere yoğunlaştığı davranışsal bir liderlik yaklaşımı olması dolayısıyla, bu tarz liderlikte yönetimsel aktiviteler ve ürün kalitesinin denetlenmesi ve finansal raporların hazırlanması gibi faaliyetler ön plandadır. Bu tür liderlerin en ayırt edici özelliği, her ne kadar örgütsel amaçlara ulaşmada en önemli araç olsa da insan kaynağını göz ardı ediyor olmalarıdır. Bu bağlamda da kişilerarası ilişkileri önemsemek yerine, örgütsel amaçlara ulaşmak için planlanan yolları takip ve çalışanların da aynı doğrultuda ilerleyip ilerlemediğini kontrol etmektedirler (Forsyth, 2010:272).

Görev yönelimli liderlerin başlıca amacı olan "yapıyı harekete geçirme"; liderin kendi görevi ya da grubun görevleri ile ilgili olarak işi ve amaçları tanımlamaya, şekillendirmeye ve harekete geçirmeye yönelik faaliyetleri kapsamaktadır. Bu kapsamda da grup faaliyetini yönetme, grup planlaması, haberleşme, programlama, yeni fikirleri uygulamaya koyma gibi faaliyetlerin gerçekleştirilmesi için liderin algılama yeteneğinin son derece yüksek düzeyde olması gerekmektedir (Yukl, 1989:5; Alkın, 2006:58). Ohio State araştırmacıları, yapıyı harekete geçirmede başarılı olan liderlerin, örgütsel üretkenliği artırmada da yüksek derecede başarılı olduklarını tespit etmişlerdir. Ancak daha düşük düzeyde bir başarı söz konusu olduğunda, örgüt içerisinde şikâyet ve işgücü devir oranı ters orantılı olarak yüksek düzeye çıkmaktadır (Robbins, 1976:357).

Görev yönelimli liderliğin, yapılması gereken işlerin en iyi biçimde ve tam vaktinde yapılıp bitirilmesi gibi önemli avantajları bulunmakla beraber görev yönelimli liderler örgüt çalışanlarına, örgütsel prosedürleri takip ederek işlerin nasıl yürüyeceğine dair örnek teşkil ederek yetki devri yapılabilmektedirler. Bu sayede de yetkilerin devredildiği çalışanların son derece verimli ve de zamanı boşa harcamayacağından emin olabilmektedirler (Anzalone, 2012).

Graen ve Uhl-Bien (1995:225)'e göre görev yönelimli liderliğin bir diğer avantajı da amaçların belirgin, tanımların anlaşılır ve kesin olmasıdır. Bu bağlamda liderler/yöneticiler, iletişimin önemini çok iyi kavramışlardır; çünkü tüm görev tanımlarının çalışanlar tarafından en iyi şekilde anlaşıldığından emin olmak istemektedirler. Dolayısıyla yalnızca lider-üye etkileşimi (Leader-Member Exchange-LMX) bağlamında bir iletişim kurmakla kalmayıp aynı zamanda belirli önemli görevler için çalışma grupları da oluşturarak her bir grup üyesinin sorumluluklarını en ince detayına kadar anlamalarını sağlamaktadırlar.

Fiedler (1964:152), eğer örgüt sağlam bir kültüre ve güçlü bir yapıya sahipse, bu tür liderlik yapısının son derece uygun olduğunu ifade etmekte ve ayrıca acil düzenlemelerde ve kriz ortamlarında da bu liderlik türünün tercih edildiğini belirtmektedir. Çünkü ulaşılmak istenen amaç için gerekli olan görevlerin ve davranışların yerine getirilmesinde; çalışanların iş tanımlarını yapacak, programlayacak ve performans standartlarını denetleyecek görev odaklı bir lidere ihtiyaç duyulmaktadır.

Öte yandan Bass (1990:49)'a göre, kurallara ve prosedürlere sıkı sıkıya bağlı olma gerekliliği başta olmak üzere bir takım temel örgütsel kurallar bu liderlik türünün çalışanlarda, kuralları çiğneme riskinden dolayı, korku hissiyatı oluşması gibi birtakım dezavantajlar oluşturabilmektedir. Korkunun yanı sıra, moral düşüklüğü ve bundan kaynaklı iş tatmini düzeyi düşüklüğü de bu tür liderliğin dezavantajları arasında kabul edilmektedir. Ayrıca, yalnızca yapılacak işlere odaklanmaktan dolayı örgüt içerisinde yaratıcılık var olamamakta, çalışanlar kendilerini robot gibi hissedebilmektedirler. Böylece, belirlenmiş görevlerinin dışında herhangi bir iş yapmak istemeyebilmekte ve bunun sonucunda da kaçınılmaz olarak iş gücü devir oranı yükselebilmektedir.

İfade edildiği üzere, diğer sektörlere nazaran rekabetin daha yoğun ve sert olduğu perakende sektöründe, müşteriye verilen hizmetin daima en üst kalitede tutulma ve bilhassa reyon ve kasa çalışanlarının müşteri isteklerine hızlı cevap verme gereklilikleri bulunmaktadır. Bundan dolayı da belirlenmiş görevlerden ziyade yeniliklere de açık olmak gereklidir. Bu da "iş gücüyle iyi ilişkiler kurarak onların görevleri dışında gönüllü davranışlar sergilemelerine, yani örgütsel vatandaşlık davranışlarına sahip olmalarına yol açmaktadır" diye düşünülebilir. 


\section{3. İlişki Yönelimli Liderlik}

İlişki yönelimli liderlik türü; çalışan tatmini, motivasyonu ve çalışanların iş-yaşam dengesi gibi faktörler üzerine yoğunlaşan davranışsal bir yaklaşımdır ve bu tarz liderler takım çalışması ve iş birliğinin önemine inanarak bunu tüm çalışanlarına benimsetmeye çalışmaktadırlar. Bunun sonucunda da ilişki davranışı; liderin kendisi ile takipçileri/çalışanları arasındaki ilişkileri güçlendirmek adına haberleşme kanallarını açması, sorumluluk devrederek astlara kendi güçlerini kullanma olanağı vermesi, böylece karşılıklı güven ve duygusal destek sağlamaya çalışması bağlamında oluşmaktadır (Eren, 2001:446). Öncelik verdikleri konu, yukarıda da değinildiği üzere, çalışanların iyiliğidir. Dolayısıyla yönetici, çalışanlarıyla vakit geçirmek ve onlarla iyi iletişim kurmak için elinden geleni yapmaktadır. Michigan grubu çalışmalarına göre ilişki yönelimli liderler/yöneticiler, kişiye ve kişisel başarılara, yüksek performans amaçları belirlemeye, çalışanlara performansa dair beklentilerin iletilmesine, kısacası kişilerarası ilişkilere önem vermektedirler (Kılıç, 2006:29-30). Bu bağlamda, ek ödemelerin, çeşitli promosyonlar vermek gibi ödüllerin ve teşviklerin yanı sıra örgüt içi çatışmaları çözmek için de çaba harcamakta, çalışanların güçlü ve zayıf yanlarının farkında olmalarını sağlamaya ve dolayısıyla iş ortamını kişiler arası rekabetin olmadığı bir alana dönüştürmeye çalışmaktadırlar (Reilly, 1968:15).

Graen ve Uhl-Bien (1995:225)'e göre ilişki yönelimli liderlik türünün en büyük avantajı yöneticinin, tüm çalışanların gönüllü olarak bir parçası olmak isteyecekleri takımlar kurmalarıdır. Takım üyeleri, yöneticileri tarafından destek göreceklerinden emin olmalarından dolayı, risk almaktan çekinmemektedirler. Böylece yaratıcılık artmakta, çalışanlar yenilikçi fikirlerini uygulamaya çalışarak örgütsel verimliliğe zorunlulukla değil içlerinden geldiği için katkıda bulunmaya çalışmaktadırlar. Bu liderlik tarzını benimsemiş yöneticiler, verimliliğin sağlanması için örgüt ortamının olumlu bir şekilde yapılandırılarak çalışanların motive edilmesi gerekliliğinin farkında olduğu için tatminsizlik, sıkıcılık, motivasyon eksikliği, çatışmalar ve iş gücü devri gibi problemlerle yakından ilgilenerek her bir çalışanının iyiliği ve mutluluğu için çaba harcamaktadır.

Öte yandan Tabarnero, Chambel, Curral ve Arana (2009:1395), ilişki yönelimli liderlik türünün avantajları olduğu gibi birtakım dezavantajlarının da bulunduğunu ifade etmektedirler. Bunlardan en önemlisi, takım ruhunun gereğinden fazla önemsenmesi durumunda yapılması gereken işlerin ve görevlerin aksayabilecek olmasıdır. Bazı yöneticiler, takımların ve takım üyelerinin gelişimine öncelik verebildikleri için, bu durum görevlerin ve projelerin önüne geçebilmektedir. Bununla beraber, çalışanların özerk oluşu, bilhassa karar alma durumlarında zorlayıcı olabilmekte ve böylece performans düşüklüğü, verimliliğin azalması ve kalitenin düşmesi gibi müşteri memnuniyetini olumsuz etkileyecek durumlar ortaya çıkabilmekte, bu da uzun vadede iş gücü devir oranının artmasına sebebiyet verebilmektedir.

Tablo 1, görev yönelimli ve ilişki yönelimli liderlik türlerini karşılaştırmalı olarak sunmaktadır:

Tablo 1. Görev Yönelimli ve İlişki Yönelimli Liderlik Türleri

\begin{tabular}{|l|l|}
\hline Görev Yönelimli & İlişki Yönelimli \\
\hline İşlerin iyileştirilmesini önemser & İlişkilerin iyileştirilmesini önemser \\
\hline Yapılar, roller ve görevlere odaklanır & İlişkiler, iyi oluş ve motivasyona odaklanır \\
\hline Beklenen çıktıların elde edilmesi önceliklidir & Olumlu ilişkiler önceliklidir \\
\hline $\begin{array}{l}\text { Amaçlara ulaşmak için açık bir plan yapılması } \\
\text { gerekliliğini vurgular }\end{array}$ & $\begin{array}{l}\text { Örgüt içerisinde takım kurmanın ve örgütsel } \\
\text { iletişimin gerekliliğini vurgular }\end{array}$ \\
\hline $\begin{array}{l}\text { Zaman çizelgelerine, adım adım ifade edilmiş iş } \\
\text { planlarna uyulmasını önemser, uyulmadığında } \\
\text { disiplin sistemini devreye sokar }\end{array}$ & $\begin{array}{l}\text { Serbest iletişimi önemser ve sık aralıklarla takım } \\
\text { toplantılarıapılması gerekliliğini vurgular }\end{array}$ \\
\hline
\end{tabular}

Kaynak: Fiedler, 1964 
Anlaşılabileceği üzere görev yönelimli liderler, iş odaklı çalışıp amaçlara ulaşmayı öncelikli olarak görüp bu doğrultuda çalışan ilişkilerini ve motivasyonu geri planda tutarken; ilişki yönelimli liderler, sonuç elde etmekten ziyade süreç içerisinde olumlu ilişkiler geliştirip çalışan motivasyonunu en üst seviyeye taşımayı ön planda tutmaktadır.

\section{4. Örgütsel Vatandaşlık Davranışı (ÖVD)}

Organ (1988:4) örgütsel vatandaşlık davranışını; "örgütün resmi ödül sistemi içerisinde doğrudan veya dolaylı olarak yer almayan ve bir bütün olarak örgütün etkili bir şekilde işlemesini sağlayan isteğe bağlı bireysel davranışlar" olarak tanımlamıştır. Kısacası, ÖVD, gönüllülük esasına dayanmaktadır (Podsakoff, Podsakoff, MacKenzie, Maynes, Spoelma, 2014:87-119).

Çalışanların örgütsel vatandaşlık davranışı sergilemesi, örgüt içerisinde birçok olumlu çıktı elde edilmesini sağlamaktadır. Örnek vermek gerekirse, Podsakoff ve MacKenzie'ye (1997:264) göre, işe yeni başlayan bir çalışana çalışma arkadaşları tarafından "gönüllü" bir şekilde sunulan destek ve yardım, yeni çalışanın örgüte adaptasyonunu hızlandıracağı gibi buna paralel olarak üretkenliğini de artırarak etkinliğin ve verimliliğin elde edilmesine olanak tanımaktadır. Buna ek olarak, örgüt üyelerince sergilenen yardımsever davranışlar, örgüt içerisindeki en iyi uygulamaların hızlı bir şekilde yayılmasında da büyük rol oynamaktadır. ÖVD, örgütün hızla değişen çevreye adapte olmasının sağlanmasında da büyük rol oynamaktadır. Şöyle ki, örgütün dış çevresiyle kendi isteğiyle ilişki halinde olan bir çalışan, çevresel değişimler hakkında bilgi sahibi olabilmekte ve böylece örgütün bütününü bu değişimler hakkında bilgilendirerek dışsal çevre şartlarına uyum sağlamaya yönlendirebilmekte ve dolayısıyla rekabet avantajı elde edebilmede yardımcı olabilmektedir. ÖVD, çalışanların moral düzeylerini yükselterek iş tatmini sağlamalarında da etkili olduğu gibi buna bağlı olarak örgütsel bağlılığın oluşmasında da büyük ölçüde bir etkiye sahip olmaktadır. Tüm bunların sonucunda da örgütsel performans artmaktadır.

Her ne kadar ÖVD, çalışanların inisiyatifinde olan, gönüllü olarak sergilenen davranışlar olsa da örgüt içerisinde destekleyici, pozitif ve ılımlı bir iklim oluşturarak yöneticilerin de çalışanlarını bu tür davranışlar sergilemeye yönlendirmeleri mümkün olabilmektedir. Bunun sonucunda ise verimlilik ve müşteri tatmini artmakta, maliyetler, devamsızlık ve iş gücü devir oranı azalmaktadır (Bitmiş, Sökmen ve Turgut, 2014:4). Bu bağlamda, dört önemli faktör ön plana çıkmaktadır (Bitmiş vd., 2014:4): grup uyumu (güveni ve tatmini artırır, grupta kalma isteği oluşturur), takım-üye etkileşimi-TMX/Team-Member Exchange (motivasyonu ve grup uyumunu sağlar), grup potansiyeli (sinerji yaratır ve iş birliğini teşvik eder) ve algılanan takım desteği (grup üyelerinin birbirlerinin iyiliğini gözetmesini sağlar). Bu faktörlerden tek birinin dahi geliştirilmesi, örgüt içerisinde, bilhassa grup/takım odaklı çalışlan örgütlerde, ÖVD sergilenmesini artırabilmektedir.

Örgüt içerisinde ÖVD sergilenmesini sağlayacak bir takım başka etkili yollar da bulunmaktadır. Bunlardan ilki, örgüt içerisindeki sosyal ortamdır. Destekleyici, iletişimin açı olduğu, lider-üye etkileşiminin yüksek olduğu bir ortama sahip örgütlerde, çalışanların ÖVD sergilemesi olanağı çok daha yüksek olmaktadır. İkinci olarak yöneticilerin farkındalık seviyesi öne çımaktadır. Astlara, üstleri tarafından planlanıp verilen eğitimler ve geliştirme aktiviteleri, yöneticiler üzerinde çalışanlarının ÖVD sergileyip sergilemediği konusunda farkındalık oluşturmaktadır. Verilen eğitimler sonrasında gösterilen performansın değerlendirilmesine göre çalışanların ÖVD göstererek performans hedeflerine ulaşmaya çalışıp çalışmadıkları rahatlıkla tespit edilebilmektedir (Bergeron vd., 2013:4).

Çalışanlar tarafından sergilenen hangi davranışların ÖVD kapsamında yer alacağı konusunda her ne kadar literatürde net bir uzlaşı olmasa da Organ (1988:4) ile Podsakoff, Mac Kenzie, Moorman, ve Fetter (1990:107142) ÖVD'yi diğergamlık (özgecilik), vicdanlllı, nezaket, centilmenlik ve sivil erdem olmak üzere beş ana kategoride sınıflandırarak bu konuda literatüre katkıda bulunmuşlardır. Bu çalışmada da ÖVD, bu beş kategori üzerinden incelenmiştir.

ÖVD kategorilerinden diğergamlık (özgecilik); yeni işe başlayan çalışana sosyalleşme aşamasında yardımcı olma ya da iş yükü ağır olan bir iş arkadaşına yardım teklif ederek yükünü azaltma gibi, içten gelerek sergilenen davranışlardır (Smith, Organ ve Near, 1983:661). Vicdanlllık (ileri görev bilinci), çalışanın yine içinden gelerek örgütün kurallarını ve prosedürlerini kabul etmesi ve denetleyen herhangi bir üstü olmamasında bile bu kural ve prosedürlere içinden gelerek uyması gibi davranışlardır (Podsakoff, MacKenzie, Paine ve Bachrach, 2000:550). Nezaket; örgüt üyeleri arasında oluşabilecek problemleri öngörmek 
ve gerekli önlemleri almak; ayrıca çalışanları etkileyebilecek konularda onlara açıklama yapmaya yönelik davranışlar gösterme eğilimi olarak tanımlanmaktadır (Organ, 1988:4). Centilmenlik; örgüt içerisinde arzu edilmeyen durumları şikâyet etmek yerine alttan alıp hoş görmeye yönelik davranışlar olarak belirtilmektedir (Organ, 1990:43-72). Sivil Erdem (yurttaşlık erdemi) ise; örgüte makro düzeyde olan ilgiyi ve bağll1ı̆̆1 temsil etmektedir. Bu ilgi, örgütün yönetimine aktif bir şekilde katılmakla ve örgütün çevresindeki fırsat ve tehditleri etkili bir şekilde izleme ile gösterilmektedir. Toplantılara katılma, fikir beyan etme ve örgüt tarafından benimsenmesinin gerekli olduğu düşünülen stratejilere dair düşünce belirtme gibi davranışlar, bu kategoride bulunmaktadır (Podsakoff vd., 2000:550; Organ, 1988:4).

\section{Metodoloji}

\subsection{Araştırmanın Amacı}

$\mathrm{Bu}$ araştırmanın amacı, yöneticilerin görev yönelimli ya da ilişki yönelimli liderlik tarzlarından hangisini benimsediğine dair çalışanların algısını ölçmek ve bu liderlik tarzlarının çalışanların örgütsel vatandaşlık davranışı sergilemeleri üzerindeki etkisini incelemektir. Bu bağlamda, Bursa ilinde faaliyet gösteren ve Türkiye'nin önde gelen marketler zincirlerinden biri olan X marketinin Bursa ili Nilüfer ilçesinde faaliyet gösteren 5 şubesindeki çalışanlar anakütle olarak ele alınmıştır. Adı geçen şubelerde ortalama çalışan sayısı 200 kişi olup bu örneklemin aynı ölçekteki diğer market zincirlerini temsil edeceği varsayılmıştır.

Toplamda 200 anket şubelere elden ulaştırılmış, 85 adet geri dönüş alınmıştır. Elde edilen veriler, SPSS 20.0 paket programinda analiz edilmiştir.

\subsection{Araştırmanın Önemi}

Literatürde, liderlik türlerine, görev yönelimli ve ilişki yönelimli liderlik türlerine ve örgütsel vatandaşlık davranışına dair yapılmış çok sayıda çalışma bulunmaktadır. Benzer şekilde liderlik türlerinin çalışanların ÖVD sergilemeleri üzerindeki etkisine dair yapılan çalışmalar da mevcuttur. Ancak, perakende sektörü çalışanlarını anakütle olarak ele alıp yine perakende sektörü yöneticilerinin benimsediği liderlik tarzlarının çalışanlar tarafından algısı ve bu liderlik tarzlarının çalışanların ÖVD sergilemesi üzerindeki etkisine ilişkin çalışmaya rastlanamamıştır. Bu bağlamda, bu çalışmanın literatüre katkıda bulunacağı düşünülmektedir.

\subsection{Araştırmanın Yöntemi}

Veri toplama yöntemi olarak anket formu kullanılmıştır. Hazırlanan anket formu, üç bölümden oluşmaktadır. İlk bölüm, katılımcıların demografik özelliklerini belirlemeye yönelik ifadeleri içermektedir. İkinci bölümde, Northouse (2004) tarafından geliştirilen "Liderlik Tarzı Ölçeği” kullanılmıştır. Ölçek, görev yönelimli (10 ifade) ve ilişki yönelimli (10 ifade) olarak 2 boyuttan ve toplam 20 ifadeden oluşmaktadır. Üçüncü bölümde ise Vey ve Campbell (2004) ile Williams ve Shiaw (1999)'ın çalışmalarından faydalanılarak Basım ve Şeşen (2006) tarafından geliştirilen "Örgütsel Vatandaşlık Davranışı Ölçeği” kullanılmıştır. Bu ölçek; özgecilik (1.-5. ifadeler), nezaket (6.-8. ifadeler), centilmenlik (9.-12. ifadeler), vicdanlılık (13.-15. ifadeler) ve sivil erdem (16.-19. ifadeler) olmak üzere 5 boyuttan ve toplam 19 madde oluşmaktadır. Ölçeğin Türkçeye uyarlaması Basım ve Şeşen (2006) tarafından yapılmıştır. Ölçekler, 5'li Likert olarak hazırlanmıştır: 1=Hiç Katılmıorum, 2=Az Düzeyde Katılıyorum, 3=Orta Düzeyde Katılıyorum 4=Katılıyorum, 5=Tamamen Katıliyorum.

\subsection{Hipotezler}

Yukarıda da değinildiği üzere, gerçekleştirilen literatür taramasında perakende sektörü çalışanlarını anakütle olarak ele alıp yine perakende sektörü yöneticilerinin benimsediği liderlik tarzlarının çalışanlar tarafından algısı ve bu liderlik tarzlarının çalışanların ÖVD sergilemesi üzerindeki etkisine dair çalışmaya rastlanamamıştır. Bu sebeple hipotezler, ortaya konulması hedeflenen bulgular kapsamında geliştirilmiştir.

$H_{1:}$ Görev yönelimli liderlik türünün, özgecilik davranışı üzerinde istatistiksel olarak anlamlı bir etkisi bulunmaktadır: $h_{1}: \mu_{1}>\mu_{2}$

$H_{2:}$ : Görev yönelimli liderlik türünün, nezaket davranışı üzerinde istatistiksel olarak anlamlı bir etkisi bulunmaktadır: $h_{2}: \mu_{1}>\mu_{2}$

$H_{3}:$ Görev yönelimli liderlik türünün, centilmenlik davranışı üzerinde istatistiksel olarak anlamlı bir etkisi bulunmaktadır: $h_{3}: \mu_{1}>\mu_{2}$ 
$H_{4::}$ Görev yönelimli liderlik türünün, vicdanlılık davranışı üzerinde istatistiksel olarak anlamlı bir etkisi bulunmaktadır: $h_{4}: \mu_{1}>\mu_{2}$

$H_{5}:$ Görev yönelimli liderlik türünün, sivil erdem davranışı üzerinde istatistiksel olarak anlamlı bir etkisi bulunmaktadır: $h_{5}: \mu_{1}>\mu_{2}$

$H_{6:}$ : İlişki yönelimli liderlik türünün, özgecilik davranışı üzerinde istatistiksel olarak anlamlı bir etkisi bulunmaktadır: $h_{6}: \mu_{1}>\mu_{2}$

H7: İlişki yönelimli liderlik türünün, nezaket davranışı üzerinde istatistiksel olarak anlamlı bir etkisi bulunmaktadır: $h_{7}: \mu_{1}>\mu_{2}$

H8: İlişki yönelimli liderlik türünün, centilmenlik davranışı üzerinde istatistiksel olarak anlamlı bir etkisi bulunmaktadır: $h_{8}: \mu_{1}>\mu_{2}$

$H_{9}$ İlişki yönelimli liderlik türünün, vicdanlılık davranışı üzerinde istatistiksel olarak anlamlı bir etkisi bulunmaktadır: $h_{9}: \mu_{1}>\mu_{2}$

$H_{10:}$ : İlişki yönelimli liderlik türünün, sivil erdem davranışı üzerinde istatistiksel olarak anlamlı bir etkisi bulunmaktadır: $h_{10}: \mu_{1}>\mu_{2}$

\subsection{Bulgular}

Yapılan güvenilirlik analizi sonucunda Liderlik Tarzları Ölçeğinin 0,955'lik, Örgütsel Davranış Ölçeğinin ise 0,920'lik bir güvenilirliğe sahip olduğu görülmüştür. Demografik bulgulara bakıldığında ise, toplam 85 katılımcının \%58.8'inin kadın, \%42.2'sinin ise erkek olduğu görülmüştür. Katılımcıların \%25.8'i evli, \%74.2'si ise bekârdır. Buna ek olarak, katılımcıların \%51.7'si 18-29 yaş grubunda, \%44.7'si 30-39 yaş grubu aralığında, \%3.6'sı ise 40-49 yaş grubundadır, 50 yaş üstü katılımcı bulunmamaktadır.

\subsubsection{Faktör Analizlerine İlişkin Bulgular}

Liderlik Tarzları Ölçeğine açıklayıcı faktör analizi uygulanmış ve yapılan faktör analizi sonucu ölçekteki maddelerin, orijinal ölçekle uyumlu olarak iki boyut altında toplandığ1 görülmüştür (Tablo 4). Bu boyutlar "Görev Yönelimli Liderlik" ve "İlişki Yönelimli Liderlik" olarak tanımlanmıştır. 1, 2, 4, 7, 15, 18 ve 19 no.lu ifadeler hiçbir faktör altında toplanmadığı için ölçüm dışı bırakılmıştır.

Tablo 4: Liderlik Tarzları Ölçeği

\begin{tabular}{llc}
\hline & \multicolumn{2}{c}{ Bileşen } \\
\cline { 2 - 3 } & 1 & 2 \\
\hline Madde 3 &, 861 & \\
Madde 5 &, 850 & \\
Madde 6 &, 810 & \\
Madde 8 &, 725 & \\
Madde 11 &, 717 & \\
Madde 12 &, 717 &, 856 \\
Madde 17 &, 692 &, 843 \\
& &, 779 \\
Madde 9 & &, 775 \\
Madde 10 & &, 693 \\
Madde 13 & &, 679 \\
Madde 14 & & \\
Madde 16 & & \\
Madde 20 & & \\
\end{tabular}

Birinci boyut olan "Görev Yönelimli” liderliğin, \%40,82'lik bir varyansa, ikinci boyut olan “ïlişki Yönelimli liderliğin ise" \%32,87'lik bir varyansa sahip olduğu görülmüştür (Tablo 5). 
Tablo 5: Açıklanan Varyans Tablosu

\begin{tabular}{|l|l|l|}
\hline Boyutlar & İfadeler & Açıklanan Varyans \\
\hline Görev Yönelimli Liderlik & $3,5,6,8,11,12,17$ & 40,82 \\
\hline İlişki Yönelimli Liderlik & $9,10,13,14,16,20$ & 32,87 \\
\hline Total & & 73,69 \\
\hline
\end{tabular}

Bu araştırmada kullanılan Örgütsel Vatandaşlık Davranışı Ölçeğine açıklayıcı faktör analizi uygulanmış ve yapılan faktör analizi sonucu ölçekteki maddelerin, orijinal ölçekten farklı olarak üç boyut altında toplandığı görülmüştür (Tablo 6). Bu boyutlar "Centilmenlik ve Nezaket", "Özgecilik" ve "Vicdanlılık" olarak tanımlandırılmıştır. Orijinal ölçekte yer alan "Sivil Erdem" alt boyutu ifadeleri, hiçbir faktör altında yer almamıştır ve dolayısıyla bu noktada Hipotez 5 ve Hipotez 10 geçersiz kılınmıştır. Bu bağlamda, hem görev yönelimli hem de ilişki yönelimli lidelik tarzı ile ÖVD boyutlarından "sivil erdem" in istatistiksel olarak anlamlı bir ilişkiye sahip olmadığı görülmüştür. 1, 5, 16, 17, 18 ve 19 no.lu ölçek maddeleri hiçbir boyutta konumlanmadığı için ölçüm dışı bırakılmıştır.

Tablo 6: Örgütsel Vatandaşlık Davranışı Ölçeği

\begin{tabular}{|c|c|c|c|}
\hline & \multicolumn{3}{|c|}{ Bileşen } \\
\hline & 1 & 2 & 3 \\
\hline Madde 15 & ,904 & & \\
\hline Madde 10 & ,896 & & \\
\hline Madde 11 & 797 & & \\
\hline Madde 7 & ,728 & & \\
\hline Madde 8 & 651 & & \\
\hline Madde 2 & & ,945 & \\
\hline Madde 3 & &, 866 & \\
\hline Madde 4 & & 861 & \\
\hline Madde 9 & & 680 & \\
\hline & & & 909 \\
\hline Madde 14 & & & ,863 \\
\hline Madde 12 & & & 859 \\
\hline Madde 13 & & & ,507 \\
\hline Madde 6 & & & \\
\hline
\end{tabular}

Birinci boyut olan Centilmenlik ve Nezaketin, \%28,91'lik bir varyansa, ikinci boyut olan Özgeciliğin $\% 27,29^{\prime}$ lik bir varyansa ve üçüncü boyut olan Vicdanlılığın \%23,75'lik bir varyansa sahip olduğu görülmüştür (Tablo 7).

Tablo 7: Açıklanan Varyans Tablosu

\begin{tabular}{|l|l|l|}
\hline Boyutlar & İfadeler & Açıklanan Varyans \\
\hline Centilmenlik ve Nezaket & $7,8,10,11,15$ & 28,91 \\
\hline Özgecilik & $2,3,4,8,9$ & 27,29 \\
\hline Vicdanlılık & $6,12,13,14$ & 23,75 \\
\hline Total & & 79,95 \\
\hline
\end{tabular}

\subsubsection{Regresyon Analizine İlişkin Bulgular}

Görev yönelimli ve ilişki yönelimli liderlik tarzlarının, örgütsel vatandaşlık davranışı boyutlarından centilmenlik-nezaket davranışları üzerindeki etkisini ölçmek üzere gerçekleştirilen regresyon analizlerinin sonuçlarına göre (Tablo 8-9), ilişki yönelimli liderlik tarzının çalışanların centilmenlik-nezaket davranışları göstermesi üzerinde istatistiksel olarak anlaml bir etkisi bulunmaktadır. Öte yandan görev yönelimli liderlik tarzinın çalışanların centilmenlik-nezaket davranışlar göstermelerinin üzerinde istatistiksel olarak anlaml bir etkisi bulunmadı̆̆ı görülmektedir. Dolayısıyla Hipotez 7 ve Hipotez 8 desteklenirken Hipotez 2 ve Hipotez 3 desteklenmemiştir. 
Tablo 8. Katsayılar Tablosu

\begin{tabular}{|c|c|c|c|c|c|c|}
\hline \multirow{2}{*}{ Aşama } & & \multicolumn{2}{|c|}{$\begin{array}{l}\text { Standartlaştırılmamış } \\
\text { Katsayılar }\end{array}$} & \multirow[t]{2}{*}{$\begin{array}{l}\text { Standartlaştırılmış } \\
\text { Katsayılar }\end{array}$} & \multirow{2}{*}{$\mathrm{t}$} & \multirow{2}{*}{$\mathrm{p}$} \\
\hline & & $B$ & Standart & & & \\
\hline \multirow[t]{3}{*}{1} & $\begin{array}{l}\text { (Centilmenlik- } \\
\text { Nezaket) }\end{array}$ & 11,744 & 1,60 & & 11,085 & , 000 \\
\hline & Görev Yönelimli & ,045 & ,061 & , 080 & 737 & ,463 \\
\hline & İlişki Yönelimli & ,381 &, 060 & 693 & 6,371 & ,000 \\
\hline
\end{tabular}

Tablo 9. Model Özeti

\begin{tabular}{|c|c|c|c|c|}
\hline Model & $\mathrm{R}$ & R Kare & $\begin{array}{l}\text { Ayarlanmış R } \\
\text { Kare }\end{array}$ & $\begin{array}{l}\text { Tahmini } \\
\text { St. } \\
\text { Sapma }\end{array}$ \\
\hline 1 & ,755a & ,570 & 500 & 2.25118 \\
\hline
\end{tabular}

Görev yönelimli ve ilişki yönelimli liderlik tarzlarının, örgütsel vatandaşlık davranışı boyutlarından özgecilik davranışları üzerindeki etkisini ölçmek üzere gerçekleştirilen regresyon analizlerinin sonuçlarına göre (Tablo 10-11), görev yönelimli liderlik tarzının çalışanların özgecilik davranışları göstermesi üzerinde istatistiksel olarak anlamlı bir etkisi bulunmaktadır. Öte yandan ilişki yönelimli liderlik tarzının çalışanların özgecilik davranışları göstermelerinin üzerinde istatistiksel olarak anlaml bir etkisi bulunmadığı görülmektedir. Dolayısıyla Hipotez 1 desteklenirken Hipotez 6 desteklenmemiştir.

Tablo 10. Katsayılar Tablosu

\begin{tabular}{|c|c|c|c|c|c|c|}
\hline \multirow[b]{2}{*}{ Aşama } & & \multicolumn{2}{|c|}{$\begin{array}{l}\text { Standartlaştırılmamış } \\
\text { Katsayılar }\end{array}$} & \multirow[t]{2}{*}{$\begin{array}{l}\text { Standartlaştırılmış } \\
\text { Katsayılar }\end{array}$} & \multirow[b]{2}{*}{$\mathrm{t}$} & \multirow[b]{2}{*}{$\mathrm{p}$} \\
\hline & & B & $\begin{array}{l}\text { Standart } \\
\text { Sapma }\end{array}$ & & & \\
\hline \multirow[t]{3}{*}{1} & (Özgecilik) & 7,143 & ,999 & & 7,148 & ,000 \\
\hline & Görev Yönelimli & ,325 & ,057 & 645 & 5,659 & ,000 \\
\hline & İlişki Yönelimli & 052 & ,056 & 105 & ,919 & 361 \\
\hline
\end{tabular}

Tablo 11. Model Özeti

\begin{tabular}{lllll}
\hline Model & & & \multicolumn{3}{c}{ Ayarlanmış R } & $\begin{array}{l}\text { Tahmini } \\
\text { St. } \\
\text { Sapma }\end{array}$ \\
\hline 1 & R & R Kare & Kare & 2.12346
\end{tabular}

Görev yönelimli ve ilişki yönelimli liderlik tarzlarının, örgütsel vatandaşlık davranışı boyutlarından vicdanlılık davranışları üzerindeki etkisini ölçmek üzere gerçekleștirilen regresyon analizlerinin sonuçlarına göre (Tablo 12-13), hem ilişki yönelimli liderlik tarzının hem de görev yönelimli liderlik tarzının çalışanların vicdanlılık davranışları göstermesi üzerinde istatistiksel olarak anlaml bir etkisi bulunmamaktadır. Dolayısıla Hipotez 4 ve Hipotez 9 desteklenmiştir. 
Tablo 12. Katsayılar Tablosu

\begin{tabular}{|c|c|c|c|c|c|c|}
\hline \multirow[b]{3}{*}{ Aşama } & & \multicolumn{2}{|c|}{$\begin{array}{l}\text { Standartlaştırılmamış } \\
\text { Katsayılar }\end{array}$} & $\begin{array}{l}\text { Standartlaştırılmış } \\
\text { Katsayılar }\end{array}$ & \multirow[b]{3}{*}{$\mathrm{t}$} & \multirow[b]{3}{*}{$\mathrm{p}$} \\
\hline & & \multirow[b]{2}{*}{ B } & \multicolumn{2}{|c|}{ Standart } & & \\
\hline & & & Sapma & Beta & & \\
\hline \multirow[t]{3}{*}{1} & (Vicdanlllık) & 17,612 & 918 & & 19,193 & ,000 \\
\hline & Görev Yönelimli & ,073 & ,053 & ,229 & 1,395 & 167 \\
\hline & İlişki Yönelimli &,- 053 & ,052 &,- 166 & $-1,013$ & ,314 \\
\hline
\end{tabular}

Tablo 13. Model Özeti

\begin{tabular}{|c|c|c|c|c|}
\hline Model & $\mathrm{R}$ & R Kare & $\begin{array}{l}\text { Ayarlanmış R } \\
\text { Kare }\end{array}$ & $\begin{array}{l}\text { Tahmini } \\
\text { St. } \\
\text { Sapma }\end{array}$ \\
\hline 1 & ,152a & ,023 & - & 1.94966 \\
\hline
\end{tabular}

6. Sonuç

Örgütsel amaçlara ulaşılması, ancak çalışanların bireysel amaçları ile örgütün stratejik amaçlarının kaynaştırılarak tek bir amaç haline getirilmesi vesilesi ile gerçekleşebilir. Bu noktada da çalışanların örgütsel amaçları adeta kendi bireysel amaçlarıymış gibi benimseyip bu amaçlara ulaşmak için çaba göstermesi de, sergileyecekleri örgütsel vatandaşlık davranışlarıyla gerçekleşebilir. "Gönüllü davranışlar" olarak da tanımlanan örgütsel vatandaşlık davranışlarının oluşması için de yöneticilerin benimsediği liderlik tarzları büyük önem teşkil etmektedir. Görev yönelimli liderler, yapılacak görevlere odaklanıp daha ziyade sonuç odaklı hareket ederken, ilişki yönelimli liderler, çalışanlarını motive etme vasıtasıyla yüksek performansa ulaşmaya odaklanıp süreç odaklı hareket etmektedirler.

Bu çalışma, Bursa ili Nilüfer ilçesinde aktif olarak faaliyet gösteren $X$ marketler zincirinin 5 şubesinin çalışanları üzerinde gerçekleştirilmiştir. Gerçekleştirilen regresyon analizlerin sonuçlarına göre ílişki Yönelimli Liderlik Tarzının çalışanların Centilmenlik-Nezaket davranışları göstermesi üzerinde istatistiksel olarak anlamlı bir etkisi bulunurken, Özgecilik ve Vicdanlılık davranışları üzerinde ise istatistiksel olarak anlamlı bir etkisi bulunmamaktadır. Buna göre liderlerin ilişki, yani çalışan odaklı bir tarz benimsemelerinin kişilerarası ilişkileri güçlendirici etkisi olmasından dolayı, çalışanların örgüt içerisinde daha nazik tavırlar sergiledikleri düşünülebilmektedir. Bununla beraber özgecilik ve vicdanlılık davranışlarının çalışanların içlerinden geldiği, liderlerinin benimsediği tarzla ilgili olmadığı düşünülebilmektedir. Öte yandan Görev Yönelimli Liderlik Tarzının ise Özgecilik Davranışları üzerinde istatistiksel olarak anlamlı bir etkisi bulunduğ $u$ görülürken Centilmenlik-Nezaket ve Vicdanlılık davranışları üzerinde istatistiksel olarak anlaml bir etkisi bulunmadığı görülmüştür. Bu bağlamda, liderlerin görev yönelimli, yani iş bitirmeye odaklı tarzları, görevleri gerçekleştirme esnasında zorluk yaşadığı görülen çalışanların iş arkadaşları tarafından yardım ve destek aldığı düşünülebilmektedir. Böyle bir durumda çalışanlar, birbirlerine gönüllü olarak yardım etmektedirler denilebilir.

Literatürde, perakende sektörünü anakütle olarak ele alıp yöneticilerin liderlik tarzlarının çalışanların ÖVD sergilemeleri üzerindeki etkisini inceleyen çalışmaya rastlanamamış olması, mevcut çalışma için bir kısıt oluşturmuş olup elde edilen bulguların mevcut literatür ile karşılaştırılması mümkün olamamıştır. Ancak, gelecekte yapılacak olan çalışmalar perakende sektörüne daha geniş bir çerçeveden yaklaşarak farklı ilçelerin, farklı şehirlerin ve araştırmalar genişleyip çeşitlendikçe tüm ülkenin bir portresinin çizilip literatüre katkı sağlamaya odaklanabilir. Profesyoneller ise bu çalışma ve buna benzer çalışmaları elde edilen sonuçları bağlamında değerlendirerek örgütleri için durum analizi yapabilir, uygun davranışları tespit edebilirler. 


\section{Kaynakça}

Alkın, C. (2006). Liderlik özellik ve davranışlarının belirlenmesi ve konuyla ilgili olarak yapılan bir araştırma. Yüksek Lisans Tezi, Trakya Üniversitesi Sosyal Bilimler Enstitüsü.

Anzalone, C. (2012). Differences between task-oriented leaders and relational-oriented leaders. Demand Media

Basım, H. N. ve Şeşen, H. (2006). Örgütsel vatandaşlık davranışı ölçeği uyarlama ve karşılaştırma çalışması. Ankara Üniversitesi SBF Dergisi, 61(4), 83-101.

Bass, B.M. (1990). Bass \& Stogdill's handbook of leadership: Theory, research, and managerial applications (3rd ed.). New York, NY: Free Press.

Bergeron, D. M., Shipp, A. J., Rosen, B. ve Furst, S. A. (2013). Organizational citizenship behavior and career outcomes: The cost of being a good citizen. Journal of Management. 39. pp. 958-984.

Borman, W. C. ve Motowidlo, S. J. (1993). Expanding the criterion domain to include elements of contextual performance. In N. Schmitt ve W. C. Borman (Eds.). Personnel selection in organizations: 7198. San Francisco: Jossey-Bass.

Bitmiş, G., Sökmen, A. ve Turgut, H. (2014). Örgütsel vatandaşlık ölçeği: Geçerlilik ve güvenilirliğinin yeniden değerlendirilmesi. Gazi Üniversitesi İktisadi ve İdari Bilimler Fakültesi Dergisi. 16(2). 1-14

Brief, A. P. ve Motowidlo, S. J. (1986). Prosocial organizational behaviors. Academy of Management Review. 11. pp. 710-725.

Eren, E., (2001), Örgütsel davranış ve yönetim psikolojisi. 7. Baskı. İstanbul: Beta Basım Yayım.

Fiedler, F. E. (1964). A contingency model of leadership effectiveness. Advances in Experimental Social Psychology. 1(1), 149-190

Forsyth, D. R. (2010). Group dynamics. (5th ed.). Belmont, CA: Wadsworth Cengage Learning.

Graen, G. B. ve Uhl-Bien, M. (1995). Relationship-based approach to leadership: Development of leadermember exchange (LMX) theory of leadership over 25 years: Applying a multi-level multi-domain perspective. Management Department Faculty Publications. Paper 57

Katz, D. ve Kahn, R. L. (1966). The social psychology of organizations. New York: Wiley.

Kılıç, G. (2006). Eğitim kurumlarında liderlik tarzları ve örgüt kültürünün performans üzerindeki etkisi. Yüksek Lisans Tezi, Erciyes Üniversitesi Sosyal Bilimler Enstitüsü.

Organ, D. W. (1988). Organizational citizenship behavior: The good soldier syndrome. Lexington, MA: Lexington Books

Organ, D. W. ve Konowsky, M. A. (1989). Cognitive versus affective determinants of organizational citizenship behavior. Journal of Applied Psychology. Vol.74, pp.157-164.

Podsakoff, P.M. ve MacKenzie, S.B. (1997). Impact of Organizational citizenship behavior on organizational performance: A review and suggestions for future research. Human Performance. Vol.10, pp.133-151.

Podsakoff, P.M., MacKenzie, S.B., Paine, J.B. ve Bachrach D.G. (2000). Organizational citizenship behaviors: A critical review of the theoretical and empirical literature and suggestions for future research. Journal of Management, Vol.26, pp.513-563.

Podsakoff, N.P., Podsakoff, P.M., MacKenzie, S. B., Maynes, T. D. ve Spoelma, T. M. (2014). Consequences of unit-level organizational citizenship behaviors: A review and recommendations for future research. Journal of Organizational Behavior, Vol.35, pp.87-119.

Podsakoff, P.M., MacKenzie, S.B., Moorman, R.H. ve Fetter, R. (1990). Transformational leader behaviors and their effects on followers trust in leader, satisfaction and organizational citizenship behaviors. Leadership 
Reilly, A. J. (1968). The effects of different leadership styles on group performance: A field experiment. Retrospective Theses and Dissertations. Paper 3510.

Robbins, S. P. (1976), The administrative process Integrating theory and practice. Prentice Hall International, New Jersey

Smith, C. A., Organ, D. W. ve Near, J. P. (1983). Organizational citizenship behavior: Its nature and antecedents. Journal of Applied Psychology. Vol.68. pp. 653-663.

Şeşen, H. ve Basım, N. (2006). Örgütsel vatandaşlık davranışı ölçeği uyarlama ve karşılaştırma çalışması. Ankara Üniversitesi SBF Dergisi. 61(4). 83-101.

Tabernero, C., Chambel, M. J., Curral, L. ve Arana, J. M. (2009). The role of task-oriented versus relationshiporiented leadership on normative contract and group performance. Social Behavior and Personality: An International Journal. 37(10). 1391-1404(14).

Tuna, M. (2007). Personel devir oranı analizi: Ankara'da yer alan yıldızlı otel işletmelerinde bir uygulama. Anatolia: Turizm Araştırmaları Dergisi, 18(1). 45-52.

Van Dyne, L., Cummings, L. L. ve Parks, J. M. (1995). Extra-role behaviors: In pursuit of construct and definitional clarity (a bridge over muddied waters). Research in Organizational Behavior, Vol.17, pp. 215-285.

Vey, M. A. ve Campbell, J. P. (2004). In role or extra-role organizational citizenship behavior: Which are we measuring? Human Performance, 17(1): 119-135

Williams, S. ve Shiaw, W. T. (1999). Mood and organizational citizenship behavior: The effects of positive affect on employee OCB intentions. The Journal of Psychology, 133(6): 656- 668

Yukl, G. A., (1989). Leadership in organizations. Englewood Cliffs, NJ: Prentice Hall

Zhang, D. (2011). Organisational citizenship behaviour. PSYCH761 White Paper, 1-14.

http://www.mindtools.com/pages/article/leader-member-exchange.htm 